\title{
SUNFLOWER PRODUCTION: HYBRIDS VERSUS OPEN POLLINATED VARIETIES ON DRY LAND
}

\author{
Pourdad, S.S. ${ }^{*}$, Beg, $^{\text {A. }}{ }^{2}$ \\ ${ }^{1}$ Dryland Agricultural Research Institute (DARI), Sararood, Kermanshah, Iran \\ 2 ICARDA Oilseed Research Program based at the Dryland Agricultural Research \\ Institute (DARI), Sararood, Kermanshah, Iran
}

Received: February 15, 2007 Accepted: March 12, 2008

\begin{abstract}
SUMMARY
Sunflower (Helianthus annuus L.) is an important oilseed crop. It was grown on more than 20 million ha in the world in 1997, of which over one million ha were in West Asia-North Africa (WANA) countries, where Iran grew 60,000 ha and Syria 50,000. There is potential for substantial increase in sunflower area and production on dry land if optimum management practices are applied. An important management consideration is choosing a high yielding, good quality variety that will maximize seed yield and minimize seed costs. This study investigated the influence of hybrids and open pollinated varieties on yield and other agronomic traits of sunflower. Ten hybrids and eleven open pollinated varieties were compared, under rainfed conditions (Jindiress) and with minimum supplementary irrigation (Tel Hadya, ICARDA Aleppo, Syria) in 1993. Soil at Tel Hadya is red clay loam characterized as Calcixerollic Xerochrept (Inceptisol), Chromic Calcixeret (Vertisol); at Jindfiress, the soil is Calcixerollic Xerochrept (Inceptisol). All of them are thermic and clayey to very fine clay. At both stations, equally good and statistically similar yields were obtained with hybrids and varieties. The average yield of the 21 cultivars was $2,207 \mathrm{~kg} / \mathrm{ha}$ at Jindiress and 2,080 kg/ha at Tel Hadya. The average yield of the 11 OPVs was $2,073 \mathrm{~kg} / \mathrm{ha}$ and that of the 10 hybrids was $2,220 \mathrm{~kg} / \mathrm{ha}$, which was similar. Thus, less costly OPVs can be used instead of costly hybrid seed. Farmer can also produce their own seed with little training; the cost will be one fourth of that of hybrids, which are imported and seldom available on time. In the absence of hybrids, $\mathrm{F}_{2}$ seed is resorted to by farmers which reduces the yields considerably. The rainfall during 1993 was lower than the long-term average; it was $277 \mathrm{~mm}$ (TH) and $417 \mathrm{~mm}$ (Jindiress). The information obtained are important to farmers, allowing them to maximize economic returns from rainfed areas by using limited supplementary irrigation in lowrainfall locations and during dry years.
\end{abstract}

Key words: sunflower, dry land, WANA, supplementary irrigation, hybrids, OPVs

* Corresponding author: e-mail: sspourdad@yahoo.com 


\section{INTRODUCTION}

Sunflower is an important crop in WANA countries. Of the 1997 sunflower area in the world, 20.24 million ha, $5 \%$ of the area and production were located in the WANA countries (FAO 1997). Turkey, Morocco, Pakistan, Iran, Iraq and Sudan were the leading producers in the WANA region. There is a need to standardize sunflower production practices for the different climatic conditions present in the region. Variety is a major input for good production along with other improved production practices leading to optimum productivity. WANA countries that grow sunflower use imported hybrid seed, which is costly and usually not readily available (ICARDA, 1993). Sunflower hybrid seed exports from the west are larger than the exports of sunflower commercial seed and sunflower oil due to greater profits in seed business. Good OPVs would be useful alternative that could be easily produced locally, even by farmers, at lower cost. The objective of this study was to compare the agronomic performance of open pollinated and hybrid varieties, and select useful varieties for local consumption.

\section{MATERIALS AND METHODS}

Twenty-one cultivars, 11 OPVs and 10 hybrids, were compared in field trials at Tel Hadya and Jindiress, the two research sites of ICARDA, Aleppo, Syria. The OPVs were from Turkey (2), Kenya (2), Romania (2), Pakistan (3) and Russia (2). The hybrids were from Yugoslavia. Planting was performed on March 3 (Tel Hadya) and March 4 (Jindiress). A RCB design with three replications was used. Plots with three rows $10 \mathrm{~m}$ long, with $40 \mathrm{~cm}$ between the rows and $15 \mathrm{~cm}$ plant distance in the row were used to obtain 65000 plants/ha. Weeding was done manually. To compensate for low rainfall, the crop at Tel Hadya received $40 \mathrm{~mm}$ of sprinkler irrigation on June 7 , at the bud stage. The soil at Tel Hadya is red clay loam with 10 Olsen P, $\mathrm{pH}$ is 8.1, characterized as Calcixerollic Xerochrept (Inceptisol), Chromic Calcixeret (Vertisol). The soil at Jindiress is Calcixerollic Xerochrept (Inceptisol), all of them thermic and clayey to very fine clay (Ryan, 1997). At Jindiress the field needed 60 $\mathrm{P}_{2} \mathrm{O}_{5}$ / ha to bring the Olsen value to 10 . Fifty $\mathrm{kg} / \mathrm{ha}$ of nitrogen were added to the experimental site before planting on 3/4 March. Previous crops at Tel Hadya and Jindiress were lentil and chickpea, respectively. Seed was overplanted and thinned to a desired plant population at 3-4 leaves stage, i.e., V2 to V3 stage (Schneiter and Miller, 1981). The crop was harvested in the first half of August.

Grain yield was taken from the central row in the plot leaving out the end plants in the row to avoid the border effect. The weight of 100 seeds was measured from a random dried sample. The other variables measured were kernel percentage, head diameter and plant height. Kernel percentage was measured from the plot yield by taking a random representative sample. Head diameter was taken from the central row in the standing crop, from 10 heads experiencing the required competition in the row and plot. Plant height was measured a day before harvest, as the distance 
from ground level to the base of the receptacle of 10 randomly selected plants from the central row. To save the seeds from bird depredation, heads were covered with cloth mesh bags after the flowers have completed anthesis. House sparrow (Passer domesticus) was the main bird pest damaging and reducing sunflower yield in this part of Syria. Soil moisture at the experimental locations was adequate at seeding; the crop was not stressed till end of May at Tel Hadya when $40 \mathrm{~mm}$ irrigation was applied. Temperatures during 1993 were lower than the long-term average.

\section{RESULTS AND DISCUSSION}

\section{Yield}

There were no statistically significant differences in yield due to location or cultivar (Table 1). Across the two sites, the highest-yielding OPV was VNIIMK $(2,466$ $\mathrm{kg} / \mathrm{ha}$ ) and the highest-yielding hybrid was NSH2 13 (2,908 kg/ha). Among the OPVs, the varieties Record and Ekis-2 were outstanding at Tel Hadya and Jindiress. Among the hybrids, NSH 111 at Tel Hadya and NSH 213 at Jindiress were highest yielding. It is worth noting that the difference between the average yields of the 11 OPVs $(2,073 \mathrm{~kg} / \mathrm{ha})$ and the 10 hybrids $(2,220 \mathrm{~kg} / \mathrm{ha})$ was non-significant and small ( $147 \mathrm{~kg} / \mathrm{ha}$ ) in relation to the yield ranges from $1,463 \mathrm{~kg} /$ ha (Ekis-2) to $2,690 \mathrm{~kg} / \mathrm{ha}$ (NSH 111) at Tel Hadya and from $1,023 \mathrm{~kg} / \mathrm{ha}(\mathrm{NSH} 102)$ to $3,443 \mathrm{~kg} / \mathrm{ha}$ (NSH 213) at Jindiress. The mean 100-seed-weight of the OPVs, $3.94 \mathrm{~g}$, was greater than that of the hybrids, $3.36 \mathrm{~g}$. However, the hybrids had a slightly greater kernel percentage, $72.6 \%$, than the OPVs, $69.9 \%$. The results also indicate that the OPVs are more tolerant of drought as their yields obtained with low moisture are equal to those of the hybrids. Means yields of individual OPVs and hybrids at the two locations are shown in Figure 1.

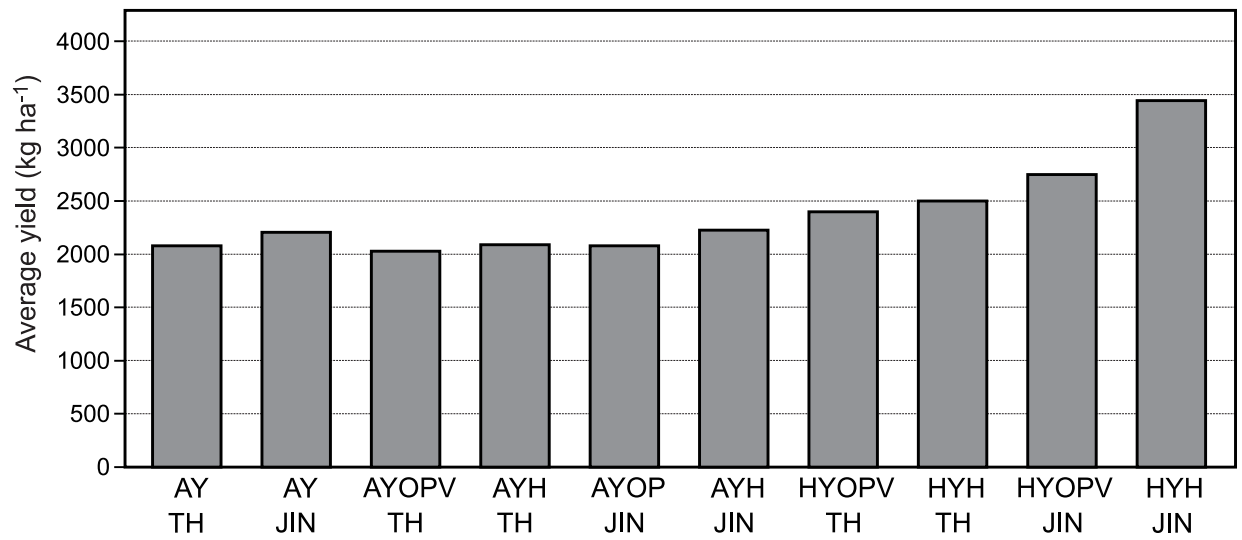

Figure1: Average yields of open-pollinated and hybrid varieties at Tel Hadya and Jinderess, 1993.

Legend: $A Y=$ average yield; $O P V=$ open-pollinated variety; $A Y O P V=$ average yield of OPV; $A Y H=$ average yield of hybrid; $H Y O P V=$ highest yielding OPV; $H Y H=$ highest yielding hybrid; $T H=$ Tel Hadya; Jin= Jindiress. 
Columns in the figure show that the average yields of the 21 varieties at the two locations were similar. The average yield of the OPVs and hybrids at Tel Hadya, a low-rain station, was about equal. Similarly, the average yield of both OPVs and hybrids was equal at the high-rain location at Jindiress. Also, the highest yielding OPV and the highest yielding hybrid at Tel Hadya had similar yields. However, the highest yielding OPV at Jindiress had a lower yield than the best hybrid, but the difference was statistically similar.

Table 1: Performance of open-pollinated and hybrid sunflower varieties at Tel Hadya and Jindiress, ICARDA, Aleppo, Syria, in 1993

\begin{tabular}{|c|c|c|c|c|c|}
\hline Factor & Yield & 100-seed wt. & Kernel & Head diameter & Height \\
\hline Location & (kg/ha) & (g) & $(\%)$ & $(\mathrm{cm})$ & $(\mathrm{cm})$ \\
\hline Tel Hadya & 2080 & 3.70 & 71.44 & 11 & 125 \\
\hline Jindiress & 2207 & 3.62 & 70.77 & 12 & 145 \\
\hline SE & 173 & 0.13 & 1.22 & 0.38 & 1.81 \\
\hline LSD & n.s & n.s & n.s & n.s & 7.80 \\
\hline \multicolumn{6}{|l|}{ Variety } \\
\hline 1. Ekis-1 & 1929 & 4.24 & 72 & 12 & 145 \\
\hline 2. Ekis-2 & 2208 & 3.98 & 74 & 12 & 145 \\
\hline 3. Fedhak & 2328 & 3.88 & 71 & 11 & 141 \\
\hline 4. $\mathrm{HO} 1$ & 2099 & 4.20 & 66 & 12 & 139 \\
\hline 5. NSH 17 & 1945 & 3.30 & 75 & 12 & 136 \\
\hline 6. NSH 26 & 1769 & 2.74 & 74 & 11 & 130 \\
\hline 7. NSH 43 & 2292 & 3.74 & 71 & 12 & 150 \\
\hline 8. NSH 97 & 2607 & 3.42 & 74 & 11 & 128 \\
\hline 9. NSH 102 & 1322 & 3.14 & 71 & 12 & 129 \\
\hline 10. NSH 104 & 2283 & 3.18 & 72 & 12 & 119 \\
\hline 11. NSH 108 & 2346 & 3.01 & 77 & 11 & 121 \\
\hline 12. NSH 110 & 2362 & 3.42 & 75 & 12 & 124 \\
\hline 13. NSH 111 & 2373 & 3.61 & 71 & 12 & 129 \\
\hline 14. NSH 213 & 2908 & 4.05 & 66 & 13 & 134 \\
\hline 15. Record/S & 2176 & 3.84 & 73 & 12 & 139 \\
\hline 16. Record/TH & 2351 & 4.27 & 68 & 11 & 147 \\
\hline 17 Shahba & 2022 & 3.99 & 71 & 11 & 137 \\
\hline 18. Shams & 1415 & 2.75 & 62 & 11 & 121 \\
\hline 19. SMT & 1948 & 3.75 & 70 & 12 & 141 \\
\hline 20. V8931 & 1871 & 3.79 & 75 & 11 & 140 \\
\hline 21. VNIIMK & 2466 & 4.66 & 67 & 12 & 144 \\
\hline SE & 402 & 0.24 & 2.41 & 0.48 & 4.26 \\
\hline LSD 5\% & n.s & 0.48 & 4.81 & 0.96 & 8.48 \\
\hline
\end{tabular}




\title{
CONCLUSION
}

The comparison of sunflower hybrids and open pollinated varieties at two locations in Northern Syria showed that the two types of cultivars had similarly good yields under the prevailing rainfed conditions. The advantage of the hybrids was that they were uniform in height and maturity, thus, they could be harvested at the same time, which is suitable for combine harvesting. However, the seed of OPVs is much cheaper than that of hybrids and farmers can save their own seed for next year.

\section{REFERENCES}

FAO, 1997. FAO Production Yearbook. Vol: 51.

ICARDA, 1993. Farm Resource Management Program Annual Report. ICARDA. Aleppo, Syria. Ryan, 1997. Soil classification of ICARDA research stations. FRMP. ICARDA Aleppo, Syria.

Schneiter, A.A and Miller, 1987. Yield and quality of semi dwarf and standard height sunflower hybrids grown at five plant populations. Agron. J. 79: 681-684.

\section{PRODUCCIÓN DE GIRASOL: HÍBRIDOS VERSUS VARIEDADES DE POLINIZACIÓN ABIERTA EN SECANO}

\author{
RESUMEN
}

El girasol (Helianthus annuus L.) es un importante cultivo oleaginoso: En 1997, se cultivó en más de 20 M ha, de las cuales más de 1 M fueron en países del oeste de Asia y norte de Africa (WANA), donde Irán cultiva 60000 ha y Siria 50000 ha. Existe potencial para un incremento sustancial de área y producción en secano utilizando óptimas prácticas de manejo. Una consideración importante en términos de manejo es la elección de una variedad de alto rendimiento y calidad que maximice los rendimientos de semilla y minimice los costos de implantación. Este estudio investigó la influencia de híbridos y variedades de polinización abierta sobre el rendimiento y otras características agronómicas del girasol. Se compararon diez híbridos y once variedades de polinización abierta bajo condiciones de secano (Jindiress) y con un mínimo de riego suplementario en Tel Hadya, ICARDA Aleppo, Siria, en 1993. El suelo en Tel Hadya es rojo, de textura arcillo limosa, caracterizado como Calcixerollic Xerochrept (Inceptisol) y Chromic Calcixeret (Vertisol); en Jindiress es Calcixerollic Xerochrept (Inceptisol), ambos térmicos y arcillosos, de arcillas muy finas. Se obtuvieron rendimientos igualmente buenos y estadísticamente similares en ambos tipos de cultivares en ambas estaciones. El rendimiento promedio de los 21 cultivares fue de $2207 \mathrm{~kg} / \mathrm{ha}$ en Jindiress y de $2080 \mathrm{~kg} / \mathrm{ha}$ en Tel Hadya. Los resultados mostraron que el rendimiento promedio de las 11 OPV fue de $2073 \mathrm{~kg} / \mathrm{ha}$ y el de los 10 híbridos de $2220 \mathrm{~kg} / \mathrm{ha}$, los que son similares, pero la semilla de las OPV es más barata, por lo que puede usarse en lugar de la semilla híbrida. Los productores pueden producir su propia semilla con poco entrenamiento; siendo el costo sólo un cuarto que el de los híbridos, que son importados y normalmente no están disponibles a tiempo. En ausencia de híbridos, los productores siembran semilla $\mathrm{F}_{2}$, lo que reduce considerablemente los rendimientos. La lluvia durante 1993 fue menor a la de los registros de largo plazo; siendo de $277 \mathrm{~mm}$ (TH) y $417 \mathrm{~mm}$ (Jindiress). La 
información obtenida es importante para que los productores maximicen los retornos económicos en áreas de secano o con muy poco riego suplementario en localidades de bajas precipitaciones y en años de sequía.

\section{PRODUCTION DE TOURNESOL: COMPARAISON ENTRE HYBRIDES ET VARIÉTÉS SUR DES TERRES SÉCHANTES}

RÉSUMÉ

Le tournesol a une importante récolte d'huile et de graines. Il a été cultivé sur plus de $20 \mathrm{~m}$ ha dans le monde en 1997, plus d'un milion d'hectares dans les pays d'Asie orientale et d'Afrique du nord (WANA) où l'Iran a cultivé 60000 ha et la Syrie 50 000. Il existe un potentiel pour une augmentation significative dans cette zone et une production en terres sèches arides avec une gestion optimale des pratiques. Une grande considération de la gestion choisit une variété de bonne qualité qui assure un haut rendement qui maximisera le rendement des graines et minimisera les coûts des semences. Cette étude a examiné l'influence des hybrides et des variétés pollinisées en plein air sur le rendement ainsi que d'autres traits agronomiques du tournesol. Dix hybrides et onze variété "open pollinated" ont été comparés, sous "rain-fed" (Jindiress) et avec une irrigation supplémentaire minimum à Tel Hadya, ICARDA Aleppo, en Syrie en 1993. La terre à Tel Hadya est constituée d'une terre glaise argileuse rouge, caractérisée comme Calcixerollic Xerochrept (Inceptisol), Chromic Calcixeret (Vertisol); à Jindfiress c'est Calcixerollic Xerochrept (Inceptisol), tous "thermic" et argileux à de l'argile très fine. Dans les deux stations, et de manière égale, de bons rendements des deux types de variétés qui ont été produites était statistiquement similaires. Le rendement moyen des 21 variétés de Jindiress était de 2207 et à Tel Hadya $2080 \mathrm{~kg} / \mathrm{ha}$. Les résultats montrent que le rendement moyen de $11 \mathrm{OPV}$ était de $2073 \mathrm{~kg} / \mathrm{ha}$ et que celui des 10 hybrides était de $2220 \mathrm{~kg} / \mathrm{ha}$, ce qui est similaire, ainsi que le moins coutant OPV peut être utilisé à la place de l'hybride, plus onéreux. Les fermiers peuvent aussi produire leur propre semence avec un peu d'entrainement; le prix en sera un quart moins cher que les hybrides, qui sont importés et rarement valables à temps. L'absence des semences d'hybrides $\mathrm{F}_{2}$, a fait ressortir pour les fermiers une baisse considérable du rendement. Les précipitations de l'année 1993 était moins importantes qu'en moyenne. Elles étaient de $277 \mathrm{~mm}$ (Tel Hadya) et $417 \mathrm{~mm}$ (Jindiress). L'information obtenue est importante pour les fermiers afin de maximiser les retours économiques des zones arrosées naturellement et des zones à irrigation limitée supplémentaire, lors de faibles précipitations locales et lors des années de faibles précipitations. 